\title{
Cross-resistance Relationships among the Aminoglucoside Antibiotics in Mycobacterium tuberculosis
}

\author{
By M. TSUKAMURA AND S. MIZUNO \\ The National Sanatorium Chubu Chest Hospital, Obu, Aichi 474, Japan
}

(Received I4 October 1974; revised 24 December 1974)

\begin{abstract}
SUMMARY
Phenotypes of isolates of Mycobacterium tuberculosis H37RV showing resistance to the aminoglucoside antibiotics streptomycin, viomycin, kanamycin, capreomycin, tuberactinomycin $\mathrm{N}$, lividomycin and paromomycin could be grouped into the following types: (I) resistant only to different levels of streptomycin; (2) resistant only to a low level of kanamycin; (3) triply resistant, to low levels of viomycin, tuberactinomycin $\mathrm{N}$ and capreomycin; (4) triply resistant, to a low level of kanamycin and high levels of lividomycin and paromomycin; (5) quadruply resistant, to a low level of capreomycin and high levels of kanamycin, lividomycin and paromomycin; (6) hextuply resistant, to high levels of viomycin, tuberactinomycin N, capreomycin, kanamycin, lividomycin, and paromomycin. Three modified types of the latter were also observed. Appearance rates of the six types were estimated as $\mathrm{IO}^{-6}$ to $\mathrm{IO}^{-9}, \mathrm{IO}^{-6}, \mathrm{IO}^{-6}$ to $\mathrm{IO}^{-7}, \mathrm{IO}^{-8}, \mathrm{IO}^{-8}$, and $1 \mathrm{O}^{-8}$ to $\mathrm{IO}^{-9}$, respectively, in a total viable population of the parent strain. Mutations to all phenotypes were considered to be produced by single mutations. According to cross-resistance relationships, aminoglucoside antibiotics were classified into three groups: (I) streptomycin; (II) viomycin, tuberactinomycin $\mathrm{N}$ and capreomycin; (III) kanamycin, lividomycin and paromomycin. No cross-resistance relationship between streptomycin and other antibiotics was observed. Resistances to viomycin, tuberactinomycin $\mathrm{N}$ and capreomycin occurred by single mutation to type 3 . Resistances to kanamycin, lividomycin and paromomycin occurred by single mutations to types 4 and 5. Low resistance to capreomycin was produced by mutation to type 5. Therefore capreomycin was considered to be an intermediate between the second and third groups. These two groups had a close relationship, as resistance to all six agents in these groups could be produced by a single mutation to type 6 (and its modified types).
\end{abstract}

\section{INTRODUCTION}

Cross-resistance relationships in Mycobacterium tuberculosis were reported first with respect to streptomycin, viomycin and kanamycin. However, resistance to kanamycin in viomycin-resistant strains and that to streptomycin in kanamycin-resistant strains was only two or four times more than the resistance levels of parent strains (Steenken, Montalbine \& Thurston, 1959; Tsukamura et al. 1959 a, b; Torii et al. I959; Tsukamura, 1959). Streptomycin-dependent strains of Mycobacterium smegmatis and their revertants remained resistant to kanamycin (Tsukamura, I96I).

The first evidence for a significant change in resistance to an agent caused by development of resistance to another agent in $M$. tuberculosis was with respect to viomycin and capreomycin resistances (Koseki \& Okamoto, I963; Verbist \& Gyselen, 1964). This relationship was extended to the relationships among viomycin, capreomycin and tuberactinomycin $\mathrm{N}$ resistances (Toyohara et al. 1969; Saito, 1972; Koseki, Okamoto \& Murohashi, 1973; 
Tsukamura, 1974). Tsukamura (1974) isolated two types of tuberactinomycin N-resistant strains of $M$. tuberculosis, one resistant to low levels of tuberactinomycin $\mathrm{N}$, viomycin and capreomycin and another resistant to high levels of tuberactinomycin $\mathrm{N}$, viomycin, capreomycin, kanamycin and lividomycin. Although highly kanamycin-resistant strains of $M$. tuberculosis were resistant to capreomycin, strains only slightly resistant to kanamycin were susceptible to it. Capreomycin-resistant strains, however, were as susceptible as the parent strains to kanamycin (Tsukamura et al. 1967; Tsukamura, 1969). Such o ne-way' cross-resistance relationships were observed also among lividomycin, kanamycin and/or capreomycin resistances, and among paromomycin, kanamycin and/or capreomycin (Tsukamura, Mizuno \& Yamamoto, 1970; Tsukamura, 1972).

Resistance patterns to aminoglucoside antibiotics are thus very complicated, and this study was undertaken in an attempt to understand more of this phenomenon.

\section{METHODS}

The test strain, Mycobacterium tuberculosis H37RV, was received from Dr S. Ata, Department of Bacteriology, Nagoya University Medical School, Nagoya, Japan, in 1947 and has since been maintained in our laboratory. The strain was purified by single-colony isolation. It was grown on Ogawa egg medium containing $100 \mathrm{ml}$ of a $\mathrm{I} \%(\mathrm{w} / \mathrm{v}) \mathrm{KH}_{2} \mathrm{PO}_{4^{-}}$ $\mathrm{I} \%(\mathrm{w} / \mathrm{v})$ sodium glutamate solution, $200 \mathrm{ml}$ whole egg, $6 \mathrm{ml}$ glycerol, and $6 \mathrm{mI}$ of a $2 \%(\mathrm{w} / \mathrm{v})$ aqueous solution of malachite green. Eight $\mathrm{ml}$ of medium were poured into I $70 \times 17 \mathrm{~mm}$ tubes and made up as slants after holding at $95{ }^{\circ} \mathrm{C}$ for $60 \mathrm{~min}$. Antibiotics were dissolved in distilled water and added to the medium before heating. The following antibiotics were used: streptomycin sulphate (Meiji Seika Co., Tokyo, Japan); viomycin sulphate (Parke, Davis \& Sankyo Co., Tokyo); kanamycin sulphate (Meiji Seika Co., Tokyo); capreomycin sulphate (Eli Lilly Co., Basingstoke, Hampshire); lividomycin sulphate (Kowa Co., Tokyo); tuberactinomycin N sulphate (Toyo Jozo Co., Shizuoka, Japan); and paromomycin sulphate (Kyowa Fermentation Co., Tokyo). The concentrations of the antibiotics were $0,10,20,30,50,100,200,500,1000$, and $2000 \mu \mathrm{g} / \mathrm{ml}$. The activity of aminoglucoside antibiotics in Ogawa egg medium is about a quarter of that in Löwenstein-Jensen medium (Tsukamura \& Tsukamura, 1963).

Isolation of resistant strains. The organism was cultivated on the Ogawa egg medium at $37^{\circ} \mathrm{C}$ for 4 weeks; the bacterial mass was homogenized by shaking with glass beads for $10 \mathrm{~min}$ and then diluted with saline $(0.9 \%, \mathrm{w} / \mathrm{v}, \mathrm{NaCl})$ to give 20 to $30 \mathrm{mg}$ wet $\mathrm{wt} / \mathrm{ml}$. A series of tenfold dilutions, to $\mathrm{IO}^{-7}$, was prepared in saline and from each a loopful $(0.02 \mathrm{ml})$ was inoculated into media containing various concentrations of antibiotic. Tubes were stoppered with a gum cap with a pin hole and incubated at $37^{\circ} \mathrm{C}$ for 4 to 8 weeks. The number of colonies was counted on media containing no agent after incubation for 4 weeks, and on media containing antibiotic after incubation for 6 weeks. Single colonies appearing after 6 to 8 weeks on media containing antibiotic were then cultivated on a medium containing no antibiotic. The resistance levels of the strains thus obtained were estimated with respect to seven antibiotics. The average rates at which resistant colonies appeared in the total viable population were calculated from ten tubes.

Measurement of resistance levels. The resistance levels of the strains, measured by an 'actual count' method (Tsukamura, 1958, 1964; Canetti et al. 1966), are expressed as the highest concentration of an antibiotic on which an inoculum of to to roo viable organisms could grow after incubation at $37^{\circ} \mathrm{C}$ for 4 weeks. The bacterial suspension was prepared as described above. 
Table I. Phenotypes of the isolates which survived on media containing various antibiotics

\begin{tabular}{|c|c|c|c|c|c|c|c|}
\hline \multirow[b]{2}{*}{ Phenotype } & \multicolumn{7}{|c|}{ Resistance level to antibiotics* $(\mu \mathrm{g} / \mathrm{ml})$} \\
\hline & SM & TUM N & VM & CPM & KM & LVM & PM \\
\hline $6 \mathrm{R}$ & $<10$ & $>1000$ & $>1000$ & $>1000$ & $>1000$ & $>1000$ & $>1000$ \\
\hline $6 \mathrm{R}^{\prime}$ & $<$ IO & $>1000$ & $>\mathrm{I} 000$ & $>1000$ & 200 & $>1000$ & $>1000$ \\
\hline $6 \mathrm{R}^{\prime \prime}$ & $<$ IO & $>1000$ & $200 \dagger$ & $>1000$ & $>1000$ & $>1000$ & $>1000$ \\
\hline 6R" & $<10$ & $>1000$ & $200 \dagger$ & $>1000$ & 200 & $>1000$ & $>\mathrm{I} 000$ \\
\hline $4 \mathrm{R}$ & $<$ IO & 10 & 20 & 200 & $>1000$ & $>1000$ & $>1000$ \\
\hline $3 \mathrm{Ra}$ & $<10$ & 10 & 20 & 20 & 200 & $>1000$ & $>1000$ \\
\hline $3 \mathrm{Rb}$ & $<10$ & 200 & $200 \dagger$ & $200 t$ & 20 & 30 & 100 \\
\hline I R & 10 & IO & 20 & 20 & 200 & 30 & 100 \\
\hline I R-sh & 1000 & IO & 20 & 20 & 20 & 30 & 100 \\
\hline I R-sm & 200 & 10 & 20 & 20 & 20 & 30 & 100 \\
\hline I R-sl & 50 & 10 & 20 & 20 & 20 & 30 & 100 \\
\hline Parent $\mathrm{H} 37 \mathrm{RV}$ & $<10$ & 10 & 20 & 20 & 20 & 30 & 100 \\
\hline
\end{tabular}

*SM, streptomycin; TUM N, tuberactinomycin N; VM, viomycin; CPM, capreomycin; KM, kanamycin; LVM, lividomycin; PM, paromycin.

$\dagger$ Either 200 or 500 .

\section{RESULTS AND DISCUSSION}

A total of 322 isolates from single colonies surviving on media containing various antibiotics were tested for resistance levels to seven antibiotics and could be classified into I I phenotypes, 6R, 6R', 6R", 6R"', $4 \mathrm{R}, 3 \mathrm{Ra}, 3 \mathrm{Rb}, \mathrm{I} \mathrm{R}$, I R-sh, I R-sm, and I R-sl (Table I). The relationships between the antibiotic used for obtaining resistant mutants and the phenotype of the isolates are shown in Table 2. The concentrations of antibiotic used were above the critical concentration, which is a point on the sigmoidal survival curve (Tsukamura, Toyama \& Tsukamura, 1963).

The proportions of various mutants of the parent $\mathrm{H} 37 \mathrm{RV}$ strain with population $10^{9}$ were calculated as the product of the appearance rate of surviving colonies and the proportion of resistant strains showing the phenotype (these are shown in Table 2). The proportions of $6 \mathrm{R}, 6 \mathrm{R}^{\prime}, 6 \mathrm{R}^{\prime \prime}$ and $6 \mathrm{R}^{\prime \prime \prime}$ mutants showed relatively large variations, from $7 \cdot 0 \times 10^{-10}$ to $8.5 \times 10^{-8}$, whereas the proportions of other mutants showed much less variation. The latter values, estimated by using different antibiotics, agreed well with each other. Appearance rate of $4 \mathrm{R}$ mutants ranged from $\mathrm{I} \cdot 2 \times 10^{-8}$ to $3.6 \times 10^{-8}$, that of $3 \mathrm{Ra}$ mutants from $\mathrm{I} \cdot \mathrm{O} \times \mathrm{IO}^{-8}$ to $3 \cdot 0 \times \mathrm{IO}^{-8}$, and that of $3 \mathrm{Rb}$ mutants from $4 \cdot 6 \times \mathrm{IO}^{-7}$ to $6 \cdot \mathrm{I} \times \mathrm{IO}^{-7}$. The appearance rates of I R, IR-sh, I R-sm, and I R-sl mutants were approximately $\mathrm{I} \times 10^{-6}$ to $2 \times 10^{-6}, 5 \times 10^{-9}, 2 \times 10^{-7}$, and $4 \times 10^{-7}$, respectively.

Stability of the mutants was confirmed: the mutants retained their resistances through three transfers on media containing no antibiotic.

The most important result obtained in the present study is that resistant mutants showing the same phenotypes have been obtained using different antibiotics, it being assumed that mutants showing the same phenotype are genetically the same. For example, $3 \mathrm{Rb}$ mutants, which are triply resistant to tuberactinomycin $\mathrm{N}$, viomycin and capreomycin, were obtained by selection with tuberactinomycin $\mathrm{N}$, viomycin or capreomycin, and it is unlikely that three different mutations, each responsible for resistance to each antibiotic, would have occurred simultaneously. Similarly, $3 \mathrm{Ra}, 4 \mathrm{R}, 6 \mathrm{R}, 6 \mathrm{R}^{\prime}, 6 \mathrm{R}^{\prime \prime}$ and $6 \mathrm{R}^{\prime \prime \prime}$ mutants also are considered as have been produced by single mutation. (As $6 \mathrm{R}, 6 \mathrm{R}^{\prime}, 6 \mathrm{R}^{\prime \prime}$, and $6 \mathrm{R}^{\prime \prime \prime}$ mutants differ only slightly in their phenotypes, these may have a common main gene and a different modifier gene.) 
Table 2. Relationship between the antibiotics used for selection and the phenotype of resistant mutant isolated

\begin{tabular}{|c|c|c|c|c|c|c|c|c|c|c|c|c|c|}
\hline \multirow{2}{*}{$\begin{array}{l}\text { Antibiotic } \\
\text { used for } \\
\text { selection }\end{array}$} & \multirow{2}{*}{$\begin{array}{c}\text { Anti- } \\
\text { biotic } \\
\text { concn } \\
(\mu \mathrm{g} / \mathrm{ml})\end{array}$} & \multirow{2}{*}{$\begin{array}{c}\text { No. of } \\
\text { surviving } \\
\text { colonies/109 } \\
\text { parent } \\
\text { bacteria* }\end{array}$} & \multicolumn{11}{|c|}{ No. of resistant strains identified, of phenotypes: } \\
\hline & & & $6 \mathrm{R}$ & $6 \mathrm{R}^{\prime}$ & $6 \mathrm{R}^{\prime \prime}$ & $6 \mathrm{R}^{\prime \prime \prime}$ & $4 \mathrm{R}$ & $3 \mathrm{Ra}$ & $3 \mathrm{Rb}$ & IR & I R-sh I & I R-sm & $|R-s|$ \\
\hline \multirow{4}{*}{$\begin{array}{l}\text { Tuberactino- } \\
\text { mycin N }\end{array}$} & 2000 & $<7$ & - & & & 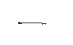 & $\cdots$ & - & - & - & - & - & - \\
\hline & 1000 & 7 & $1 \dagger$ & - & - & - & - & - & - & - & - & - & - \\
\hline & 500 & $82(7)$ & $1 \dagger$ & - & $\ldots$ & - & - & - & 10 & - & - & - & - \\
\hline & 200 & $460(7)$ & $1 \uparrow$ & - & - & 一 & - & - & 10 & - & - & - & - \\
\hline \multirow[t]{5}{*}{ Viomycin } & 2000 & $<\mathrm{I}$ & - & - & - & - & - & - & -- & - & - & - & - \\
\hline & 1000 & $2 \mathrm{I}$ & 一 & 1 & - & $\ldots$ & 一 & 一 & 9 & - & - & 一 & - \\
\hline & 500 & 584 (I9) & - & $4 \dagger$ & - & - & - & - & 6 & - & - & - & - \\
\hline & 200 & 612 & - & - & - & - & - & - & 26 & - & - & - & - \\
\hline & 100 & 810 & - & - & - & - & - & - & 10 & - & - & - & - \\
\hline \multirow[t]{4}{*}{ Capreomycin } & 2000 & $<\mathrm{I}$ & - & 一 & - & 一 & - & -- & 一 & - & - & $\ldots$ & - \\
\hline & 1000 & 7 & - & - & - & I & - & - & 9 & - & - & - & - \\
\hline & 500 & 360 & - & - & - & - & - & - & 10 & - & - & - & -- \\
\hline & 200 & 520 & - & - & - & - & - & I & 26 & - & 一 & - & - \\
\hline \multirow[t]{5}{*}{ Kanamycin } & 2000 & 2 & I & - & - & - & - & -- & - & - & - & - & - \\
\hline & 1000 & $2 \mathrm{I}$ & I & - & - & - & 9 & - & - & - & - & - & -- \\
\hline & 500 & 119 (14) & $1 \dagger$ & - & - & - & $6 \dagger$ & - & - & 3 & - & - & - \\
\hline & 200 & 1200 & - & - & - & - & - & $\mathrm{I}$ & - & 39 & - & - & $\ldots$ \\
\hline & 100 & I 800 & - & - & - & - & 一 & - & - & 20 & - & - & - \\
\hline \multirow[t]{3}{*}{ Lividomycin } & 2000 & $<$ I & - & - & - & - & - & - & - & - & - & - & - \\
\hline & 1000 & 21 & - & - & - & 3 & 9 & - & - & - & - & - & -.. \\
\hline & 500 & $42(21)$ & $3 \dagger$ & - & - & - & 12 & 4 & - & - & - & -- & -- \\
\hline \multirow[t]{2}{*}{ Paromomycin } & 2000 & 72 & - & - & 8 & - & - & - & - & 一 & - & - & $\cdots$ \\
\hline & 1000 & I 45 & 7 & 1 & 20 & 5 & 14 & 9 & - & - & - & - & - \\
\hline \multirow[t]{4}{*}{ Streptomycin } & 2000 & 5 & - & - & - & -- & - & -- & - & - & I & - & - \\
\hline & 1000 & 5 & - & - & - & - & - & - & - & - & 1 & -- & - \\
\hline & 200 & 210 & - & - & - & - & - & - & - & - & - & 10 & - \\
\hline & 20 & 710 & - & - & - & 一 & - & - & - & - & - & 4 & \\
\hline
\end{tabular}

* The number in parenthesis is the number of large colonies when the growth consisted of a mixture of large and small colonies.

$\uparrow$ Strains from large, eugonic colonies.

At present, complicated features of cross-resistance relationships can be seen. Thus, mutants obtained by selection with $200 \mu \mathrm{g}$ kanamycin/ml are resistant only to kanamycin, but mutants obtained by selection with $500 \mu \mathrm{g}$ kanamycin $/ \mathrm{ml}$ are resistant to both kanamycin and capreomycin. On the other hand, mutants obtained by selection with a low concentration of capreomycin remain susceptible to kanamycin (Tsukamura et al. 1967; Tsukamura, 1969). Thus there is a 'one-way' cross-resistance relationship between kanamycin and capreomycin; until now, it has been difficult to explain this phenomenon simply.

Previously, it was supposed, a priori, that resistance to two agents, A and B, always stemmed from two different mutations. Accordingly, a 'complete' (two-way) crossresistance phenomenon was explained by supposing that different mutations produced the same phenotype, and a 'one-way' cross-resistance phenomenon was explained by supposing that a mutation giving resistance to A caused secondary metabolic change which resulted in resistance to $\mathrm{B}$, whereas the mutation giving resistance to $\mathrm{B}$ caused no such secondary change. However, it appears from the present study that 'complete' (two-way) crossresistance is produced by a single gene-mutation, and the 'one-way' cross-resistance 
Table 3. Classification of antibiotics by cross-resistance relationships

Extent of resistances shown by various phenotypes of mutants

\begin{tabular}{|c|c|c|c|c|c|c|c|c|c|c|}
\hline Group & Antibiotics & $\begin{array}{l}\text { I R-sh, } \\
\text { I R-sm and } \\
\text { I R-sl }\end{array}$ & I R & $3 \mathrm{Rb}$ & $3 \mathrm{Ra}$ & $4 R$ & $6 \mathrm{R}$ & $6 \mathrm{R}^{\prime}$ & $6 \mathrm{R}^{\prime \prime}$ & $6 \mathrm{R}^{\prime \prime \prime}$ \\
\hline I & Streptomycin & $R-r$ & -- & 一 & - & - & - & - & - & - \\
\hline II & $\begin{array}{l}\text { Tuberactinomycin } \mathrm{N} \\
\text { Viomycin } \\
\text { Capreomycin }\end{array}$ & - & 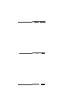 & $\begin{array}{l}\mathrm{r} \\
\mathrm{r} \\
\mathrm{r}\end{array}$ & - & - & $\begin{array}{l}\mathrm{R} \\
\mathrm{R} \\
\mathrm{R}\end{array}$ & $\begin{array}{l}\mathrm{R} \\
\mathrm{R} \\
\mathrm{R}\end{array}$ & $\begin{array}{l}\mathrm{R} \\
\mathrm{r} \\
\mathrm{R}\end{array}$ & $\begin{array}{l}\mathrm{R} \\
\mathrm{r} \\
\mathrm{R}\end{array}$ \\
\hline III & $\begin{array}{l}\text { Kanamycin } \\
\text { Lividomycin } \\
\text { Paromomycin }\end{array}$ & $\begin{array}{l}- \\
- \\
-\end{array}$ & $\frac{r}{-}$ & $\begin{array}{l}- \\
-- \\
-\end{array}$ & $\begin{array}{l}\mathrm{r} \\
\mathrm{R} \\
\mathrm{R}\end{array}$ & $\begin{array}{l}\mathrm{R} \\
\mathrm{R} \\
\mathrm{R}\end{array}$ & $\begin{array}{l}\mathrm{R} \\
\mathrm{R} \\
\mathrm{R}\end{array}$ & $\begin{array}{l}\mathrm{r} \\
\mathrm{R} \\
\mathrm{R}\end{array}$ & $\begin{array}{l}\mathrm{R} \\
\mathrm{R} \\
\mathrm{R}\end{array}$ & $\begin{array}{l}\mathrm{r} \\
\mathrm{R} \\
\mathrm{R}\end{array}$ \\
\hline $\begin{array}{l}\text { Appear } \\
\text { amons } \\
\text { tion o }\end{array}$ & $\begin{array}{l}\text { ance rate of mutants } \\
\text { total viable popula- } \\
\text { f the parent } \mathrm{H} 37 \mathrm{RV}\end{array}$ & $\begin{array}{l}10^{-0} \\
\text { to } \\
10^{-4}\end{array}$ & $10^{-6}$ & $\begin{array}{c}10^{-6} \\
\text { to } \\
10^{-7}\end{array}$ & $10^{8}$ & $10^{-8}$ & $\begin{array}{l}10^{-8} \\
\text { to } \\
10^{-9}\end{array}$ & $\begin{array}{l}10^{-8} \\
\text { to } \\
10^{-9}\end{array}$ & $10^{-8}$ & $\begin{array}{c}10^{-8} \\
\text { to } \\
10^{-9}\end{array}$ \\
\hline
\end{tabular}

$\mathrm{R}$, Resistance to more than $1000 \mu \mathrm{g} / \mathrm{ml} ; \mathrm{r}$, resistance to 200 to $500 \mu \mathrm{g} / \mathrm{ml}$ (excluding the case of streptomycin); $\mathrm{R}-\mathrm{r}$, resistance to between 500 and $1000 \mu \mathrm{g} / \mathrm{ml}$.

relationship reveals different kinds of mutants. Reports on the 'one-way' cross-resistance relationship between kanamycin and capreomycin resulted from the observation of two types of mutants: $4 \mathrm{R}$, which is resistant to kanamycin, lividomycin, paromomycin and capreomycin; and $3 \mathrm{Rb}$, which is resistant to capreomycin, viomycin and tuberactinomycin $\mathrm{N}$. The former $\left({ }_{4} \mathrm{R}\right)$ was selected by kanamycin and the latter $(3 \mathrm{Rb})$ by capreomycin. The former has not easily been selected by capreomycin because of the difference in appearance rates of $4 \mathrm{R}$ and $3 \mathrm{Rb}\left(\mathrm{IO}^{-8}\right.$, and $10^{-6}$ to $10^{-7}$, respectively). Both $4 \mathrm{R}$ and $3 \mathrm{Rb}$ have a chance of being selected by capreomycin, but the latter has a greater chance.

There appear to be different mechanisms of resistance, each due to single gene-mutation. There are three types of capreomycin-resistant mutants, $3 R b, 4 R$ and $6 R\left(6 R^{\prime}, 6 R^{\prime \prime}\right.$ and $\left.6 R^{\prime \prime \prime}\right)$, four for kanamycin resistance ( $I R, 3 R a, 4 R$ and $6 R$ ), two for viomycin resistance (3Rb and $6 \mathrm{R})$, two for tuberactinomycin $\mathrm{N}$ resistance ( $3 \mathrm{Rb}$ and $6 \mathrm{R})$, three for lividomycin resistance $(3 \mathrm{Ra}, 4 \mathrm{R}$ and $6 \mathrm{R})$ and three for paromomycin resistance $(3 \mathrm{Ra}, 4 \mathrm{R}$ and $6 \mathrm{R})$. Among these, at least four produce cross-resistance. These are $3 R a, 3 R b, 4 R$ and $6 R$ $\left(6 R^{\prime}, 6 R^{\prime \prime}\right.$ and $6 R^{\prime \prime \prime}$ may be further types.)

The $6 \mathrm{R}$ mutants were obtained by selections with kanamycin, lividomycin, paromomycin, and tuberactinomycin $\mathrm{N}$ but not with capreomycin even though the mutants were highly resistant to capreomycin. At present, we have no real explanation for this phenomenon.

Aminoglucoside antibiotics can be classified into three groups according to their crossresistance relationships (Table 3). Group I would consist only of streptomycin, group II would contain viomycin, tuberactinomycin $\mathrm{N}$ and capreomycin, and group III contain kanamycin, lividomycin and paromomycin. The resistances to the antibiotics of group II are covered by the $3 \mathrm{Rb}$ mutants, and those to the antibiotics of group III by the $3 \mathrm{Ra}$ and $4 \mathrm{R}$ mutants. Though capreomycin is placed in group II in the Table, it is considered to be an intermediate between groups II and III, as the mutants $4 \mathrm{R}$ cover this together with the antibiotics of group III. Groups II and III are closely related to each other, as the resistances to these six antibiotics are covered by the $6 \mathrm{R}$ mutants $\left(6 \mathrm{R}^{\prime}, 6 \mathrm{R}^{\prime \prime}\right.$ and $\left.6 \mathrm{R}^{\prime \prime \prime}\right)$. Streptomycin is clearly differentiable from these six. 


\section{REFERENCES}

Canetti, G., Armstrong, A. R., Bartmann, K., Cetrangolo, A., Hobby, G. L., Lucchesi, M., Stewart, S. M., Sula, L., Tsukamura, M. \& Schmiedel, A. (I966). Recent progress in drug resistance tests for tubercle bacilli (major and minor drugs). Bulletin of the International Union against Tuberculosis 37, I $85-225$.

KoSEKI, Y. \& Окамото, S. (I963). Studies on cross-resistance between capreomycin and certain other anti-mycobacterial agents. Japanese Journal of Medical Science and Biology 16, 3 I-38.

Kosexi, Y., Окамотo, S. \& Murohashi, T. (1973). Antituberculous activities of the tuberactinomycins in vitro and in experimental animals. Kekkaku 48, 189-196.

SAITo, T. (1972). Cross resistance of tubercle bacilli to KM, VM, CPM, LVM and TUM. Japanese Journal of Tuberculosis and Chest Diseases 18, 7-19.

Steenken, W., Montalbine, V. \& Thurston, J. R. (I959). The antituberculous activity of kanamycin in vitro and in the experimental animal (guinea pig). American Review of Tuberculosis 79, 66-7I.

Tori, F., Yamamoto, M., Hayashi, M., Noda, Y. \& Tsukamura, M. (1959). Studies on the kanamycinresistance of Mycobacterium tuberculosis. II. Kanamycin-sensitivity of various drug-resistant strains. Journal of Antibiotics A 12, 103-104.

Toyohara, H., Nagata, A., Hayano, K. \& Abe, J. (I969). Study on the antituberculous activity of tuberactinomycin, a new antimicrobial drug. American Review of Respiratory Disease 100, 228-230.

Tsukamura, M. (1958). Drug resistance test for kanamycin resistance of tubercle bacilli. Medicine and Biology (Tokyo) 49, 87-90.

Tsukamura, M. (1959). Further studies on the one-way cross-resistance in Mycobacterium tuberculosis with special reference to streptomycin resistance, kanamycin resistance, and viomycin resistance. Japanese Journal of Genetics 34, 275-28I.

Tsukamura, M. (1961). Biological and biochemical studies on the streptomycin-dependent mutants of a Mycobacterium (Jucho). I. Morphological characteristics and relationship between streptomycin dependence and kanamycin resistance. Iryo 15, 30-35.

Tsukamura, M. (1964). 'Actual count' method for the resistance test of tubercle bacilli. Japanese Journal of Tuberculosis 12, 46-54.

Tsukamura, M. (1969). Cross-resistance relationships between capreomycin, kanamycin and viomycin resistances in tubercle bacilli from patients. American Review of Respiratory Disease 99, 780-782.

Tsukamura, M. (1972). Cross-resistance relationships between paromomycin (aminosidine), lividomycin, kanamycin, and capreomycin resistances of Mycobacterium tuberculosis. Chemotherapy (Tokyo) 20, 687-694.

Tsukamura, M. (1974). Resistance pattern to tuberactinomycin-N and cross resistance relationships between tuberactinomycin-N, lividomycin, capreomycin, viomycin, kanamycin and streptomycin resistances of Mycobacterium tuberculosis (H37Rv). Chemotherapy (Tokyo) 22, III5-I I 2 I.

Tsukamura, M., Mizuno, S. \& Yamamoto, M. (I970). Antituberculous action of a new antibiotic, lividomycin. Effect on experimental tuberculosis of mice and cross resistance with other antituberculous agents. Kekkaku 45, 263-272.

Tsukamura, M., Noda, Y. \& Yamamoto, M. (I959a). Studies on the kanamycin resistance in $M y c o b a c-$ terium tuberculosis. V. Sensitivity of kanamycin-resistant mutants to various antituberculous drugs and mutation frequency to various drug resistance in kanamycin-resistant mutants. Journal of Antibiotics A 12, 323-327.

Tsukamura, M., Noda, Y., Yamamoto, M., Hayashi, M. \& Toril, F. (1959b). Cross-resistance problem of Mycobacterium tuberculosis with special reference to kanamycin resistance. Medicine and Biology (Tokyo) 50, 4-9.

Tsukamura, M., Toyama, H., Mizuno, S. \& Tsukamura, S. (1967). Cross resistance relationship among capreomycin, kanamycin, viomycin and streptomycin resistances of Myocbacterium tuberculosis. Kekkaku 42, 399-404.

Tsukamura, M., Toyama, H. \& Tsukamura, S. (I963). Resistance pattern of Mycobacterium tuberculosis to cycloserine. Japanese Journal of Tuberculosis II, 36-43.

Tsukamura, S. \& Tsukamura, M. (I963). Comparison of the degree of drug resistance between ' $1 \%$ Ogawa medium' and 'Lowenstein-Jensen medium'. Japanese Journal of Tuberculosis 11, 44-47.

VERBIST, L. \& GYSELEN, A. (1964). Capreomycin susceptibility of strains resistant to streptomycin and/or viomycin. American Review of Respiratory Disease 90, 640-641. 